\title{
From the Diary
}

\section{Hikmat Niyazi oqlu Vazirov \\ vezirov55@mail.ru}

\begin{abstract}
A completely new approach to a very interesting and popular issue of ancient and even modern times - problem of Judah's betrayal is considered in this article written in novel genre. It is shown that actually betrayal didn't happen. On the contrary, Judah consciously sacrificed his own and Jesus's life to save the humanity. Thus, Judah is not a betrayer, but a martyr-hero. As imam Hussein consciously sacrificed his and his family's lives to save and preserve the Islam. Thereby, Judah and Imam Hussein are the great martyr-heroes in the history.
\end{abstract}

\section{Аннотаичя}

Предложенная читателю крохотка (новелла-миниатюра) - это “перевод” “дневника” апостола Иуды с арамейского и древнегреческого языков. Из оборванных мыслей и записей Иуды становится понятным, что он вовсе не предавал Христа (Учителя), а лишь претворил в жизнь придуманный им самим же план помощи Христу и спасения человечества, которое, как думал Иуда, без Учения Христа сгинуло бы, а Учение без предательства забылось бы. До слов “две тысячи лет ненависти” Иуда писал дневник в своей земной жизни, начиная же с этих слов Иуда продолжает свой дневник в раю. Иуда объясняет, что Бог (Он) только теперь разрешил ему рассказать людям, как все было на самом деле. Для этого Иуда передал свой дневник автору настоящей новеллы-крохотки. Иуда в дневнике намекает, что его роль в аресте Учителя ничтожна - Христа же в лицо знали все: и государство, и ненавидившие Его попы, и зеленщики, и солдаты... и слушали каждый день.

Дневник Иуды - это также первоисточник правды об имаме Хусейне, внуке пророка Мухаммеда (Деда). Оказывается, имам Хусейн принес и себя, и все свое семейство (72 души) в жертву тоже осознанно, и тоже ради спасения человечества, которое, как он думал, без Учения его Деда пропало бы. Впервые в истории показано, что именно Иуда предлагает людям не обижать рыб и другую бессловесную живность. Из дневника явствует, что Иуда возмущен злодейством фашистов и дашнакских палачей, натворивших Ходжалы и Саласпилс. И он уже сомневается, станут ли они когда-нибудь человеками.

Настоящая крохотка (новелла-миниатюра) охраняется Законом АР Об авторском праве и смежных правах (свидетельство №10194 от 05.06.2018).

... предателей не любят... предательство помнят. Помнят долго. Главное, что люди никогда не забудут моё... “предательство”. Всегда будут помнить. И ничего со мной не случится, если даже сотню лет будут проклинать меня. За то, что я предал Учителя. Создателя Учения. Ведь Он же никогда не внушит мне предать Учителя. И Учитель никогда бы не предал меня... внушив мне предать Его Самого. Нет. Это не можно. Иначе это не было бы Учением, а был бы Его грех. А намек на то, что один из вас предаст меня - так на то и Учитель: все знает! Это не внушение... Надежда, предвосхищение... предвкушение... 
Только я́ додумался “предать” Его. Потому я - и ученик любимый. Учитель знает, кого любить больше. Ни разу меня бараном не назвал. Одна кровь... И тетя Мария... все знала... и даже не пыталась отговорить меня... По-другому же Учения не спасти... И людей тоже... Ведь люди не будут помнить Учения без чего-то великого. Я их хорошо знаю: ведь сколько Их было до Учителя... А Учение еще такое хрупкое, беззащитное... Придется предать Учителя подло, из “корысти”... Уф!.. с наветом... Такое вы́зовет всеобщую ненависть. Хорошо бы за тридцать монет... Нет, не золотых, пожалуй. Лучше, серебряных. Но, думаю, этого все же недостаточно. Надо, чтобы люди ду́мали ка́к я мучился. Значит, решено!.. Повеситься!.. Но... только после того, как все узна́ют, что Учитель “воскрес... живой (ведь такое уже было)... И так, чтобы напоминало Учение... Значит, на смоковнице, фиге... винная ягода, инжир. Нет. Мало. Люди могут забыть. Надо бы обнять и поцеловать Учителя. Вот тогда будут помнить долго. Долго будут помнить, ка́к Учитель страдал... ка́к я обрек Его на это. Будут помнить мое “предательство” и страдания Учителя - никогда не забудут Учения... Да, еще... Не забыть бы вернуть деньги... Только сыграть искусно, чтоб не догадались... И ученики... И чтобы написали, что я - предатель...

Один Он знал, зачем я все это сделал... А люди... - только через пару сотен лет... Ведь им и в голову не придет хотя бы задуматься о том, что Учителя же все знали в лицо: и государство, и попы, и зеленщики, и солдаты, и уличные... Учитель же и Сам без никого мог бы придти и отдать Себя им в руки... но... нужно же свидетельство... против Него...

... две тысячи лет ненависти. Две тысячи лет они думали, что я на самом дне. Вот глупые. А меня же там не было никогда. Даже мудрый Хайям думал, что я - предатель: “... среди апостолов и то... один - предатель” ... А я ведь спас их. Не будь же Учения - не было бы и их... а не будь моего “предательства", не сохранилось бы Учение ... И Данте заблуждался, думая, что я в аду... И зря судил... Мы с Дедом и Али ему только померещились... И Варнава врет... Не может же Он обманывать... и сделать так, чтобы вместо Учителя распяли меня или другого невинного человека... Наверное, потому и говорил Учитель: “Не судите”... Только Он знал, что не настоящий предатель я. Я только подсобил Учителю... Ведь будь я настоящим предателем... Дед в своем Писании сказал бы об этом... И первым меня прокляла бы тетя Мария... Не прокляла же... Но... церковь или не понимает, или же не хочет говорить правду обо мне... ведь когда я их привел, я же сказал: радуйся, Равви... Матфей слышал... но... не то понял... как хорошо... не понял... Пришло время и людям узнать... правду. О́н разрешил. Теперь можно...

А как я все это провернул?!. Какая игра?!. Ай да молодец!.. Даже Матфей, и Марк, и Лука, и Иоанн... А что же ученики?.. Защитили Учителя?.. Отреклись?!. Убежали?!. Хороши... Даже Петр?.. его падение... А ведь ни один из них в своём Писании ничего не сказал о своем “подвиге”... Как же верить им до конца?.. Петра и других простили... и возвеличили... А предатель - я?!. До сих пор?!. Сохранителя... ?!. Только Мария-ученица... А тезки здесь нет...

Другие шахиды-мученики тоже здесь. Часто вижу Хусейна. Ибн Али. Все его семейство и челядь здесь. Вот он - действительно молодец. Герой. Какая великая душа. Какая отвага. Это тебе не я. Одному-то легче. А каково было ему. Знать, что́ сделают с твоим семейством, и 
отдать всех. 72 человека. Осознанно. Так же осознанно, как и я принес в жертву и Учителя, и себя. Ради Учения для людей... А его предали?.. А воду?.. А руку?.. Натворивших это злодейство я здесь не видел. В любом случае, он большая умница. Как все рассчитал... Почти полторы тысячи лет люди помнят и это... но уже настоящее, подлое злодейство и предательство. Помнят, ка́к страдал Хусейн. Мученик. Праведник. Отмечают каждый год. Целых сорок дней скорби. Сработало. Без его подвига могли бы забыть и следующее Учение. Учение его Деда. Хотя?.. Какое Оно следующее?.. Оно же то же самое, только подчищенное и подправленное - ведь что-что, а пачкать и портить совершенное люди так хорошо умеют. Вот Он и наказал исправить, подчистить, подправить... что Дед и сделал. Здесь Хусейну тоже хорошо. Живем рядом. Часто беседуем с Учителем. Учитель его уважает, а с его Дедом дружит... Одна же кровь... У Деда и Али обиды прошли - дело-то общее сделали. А обиды были?.. А Он любит нас всех.

Мы оба принесли жертву осознанно. Сами. Без никакого из людей. И Учитель здесь признался, что я поступил правильно... И мы с Ним не сговаривались!.. Правда!.. Здесь Хусейна и меня почитают двумя са́мыми великомучениками...

А люди там?.. Мыслят Учения?.. И никак эти глупые не поймут, что Он - один, и другого нет... И ничего нет... И все кончится... И начнется с начала... Вот неразумные... И зачем им все это?!. Не ведают, что творят!.. И чего им не живется?!. О́н же повелел!.. И дозволил!..

Случайно услышал, как Дед говорил Учителю, что так эти люди ничего и не поняли... надо бы спросить с них... Видать, пора... Самое время. Надо бы кому-то придти туда снова. И еще раз объяснить, чтоб не ждали прихода другого... И одумались... И пусть все ходят друг к другу... И в мечеть... И в церковь... И в синагогу... Особенно там... О́н велит... Он же один... Только имен много. Это же Его́ дома... А разногласия... так в каждом же доме... ... а рыбы?.. Этим людишкам не жалко рыб?!. А в чем они виноваты? Только в том, что О́н сделал их такими... бессловесными... Если они не умеют мычать, кукарекать, пищать, чирикать или говорить, значит... их можно мучить?.. За что?.. Они жалеют даже глупую курицу... Только за то, что она шумит. А рыбы не умеют. Поэтому их можно вытащить из воды, и ждать, когда сдохнут?.. Им все равно?.. Они же задыхаются... Мучаются... Долго... Часами... Перед смертью они подвергаются страшным пыткам... Какая жестокость!.. Неужели люди не понимают, что это ужасно?..

О́н так сделал, чтобы волки кушали зайцев, кошки ели мышей. Наверное, та́к нужно. Кушают, но не мучают же. Медведи ловят рыб и едят. Не мучают. Они сразу умирают... А люди?.. Разве О́н им сказал, что рыб нужно мучить?.. В Писаниях так не сказано. Даже рыбы это знают. А они - нет!.. Не читают же... А ведь Писание потому и названо "Чтение”, “Читай”, “Книга”, “Учебник” или “Учение”, чтобы люди учились... Жить... Но они этого не понимают. Они даже не понимают, что Он назидательно испы́тывает их... Он же сделал рыб бессловесными, чтобы люди са́ми додумались... А они не понимают... Куда смотрят законодатели... и эти... зеленые?..

... а детей?.. а Ходжалы?.. а Саласпилс?.. Разве О́н научил их этому?!. Станут ли они человеками?.. Когда-нибудь?.. 
... и потому... судите, да побиты и блаженны будете... а может... не судимы будете...

Translation of the Title and affiliation to the Author's Language

ИЗ ДНЕВНИКА

(перевод с арамейского и древнегреческого)

\section{Хикмет Ниязи оглу Везиров,}

Руководитель лаборатории Института физики Национальной Академии наук

Азербайджана, г. Баку

vezirov55@mail.ru 